\section{Australians protest limit on support for gravity research}

Sydney. Australian scientists are disappointed at a decision by the Australian Research Council (ARC) to provide less than half the funding requested by a consortium of research groups involved in an international project to develop gravitational wave detectors.

Although the project grant awarded to the consortium - $\mathrm{A} \$ 1.25$ million (US\$937,000) over three years - is the biggest ever made by the research council, it is still considerably less than the A\$3 million the consortium had asked for.

Mary O'Kane, the chair of the council's research grants committee, says that the decision reflects the pressure on the council in allocating its limited funds.

But John Sandeman, professor of physics at the Australian National University in Canberra, ACT, who coordinated the consortium that made the bid, points out that the grant contrasts sharply with the US $\$ 250$ million being put into the project by the US government and US $\$ 100$ million by a joint French-Italian contribution.

Sandeman says that the shortfall in the grant will mean cuts in research projects in which Australia is among the world leaders. Some of those involved in the grants process "did not understand" the nature of the application, he said.

The grant was made under ARC's large grants programme, which accounts for A $\$ 83$ million of the A $\$ 200$ million awarded annually by the council; the rest is distributed through a series of schemes, including support for special centres and fellowships.

Even so, the council, which is the largest source of funding for pure science in Australia, has been able to support only 22 per cent of the 3,004 applications for large grants.

O'Kane says that she sympathizes with Sandeman's disappointment, but argues that the only solution is for the government to increase the money available for the large grants programme to $\$ 200$ million.

According to Sandeman, the joint application was really six-seven large grant applications rolled into one, in order to support work by research groups at several universities. These include one headed by David Blair at the University of Western Australia in Perth, who is working on ways of isolating the proposed detectors from interference, and another at the University of Adelaide headed by Jesper Munch, which is developing the laser equipment required.

Sandeman said that the planned work, which is an essential part of the international project, will have to be pruned to meet the new budget restrictions. But he does not yet know which areas are likely to be cut back.

Mark Lawson

\title{
'Car of the future' project off to bumpy start, says panel
}

Washington. The Clinton administration's flagship technology programme to develop more fuel-efficient cars has been strongly criticized by a National Academy of Engineering panel for lacking either a proper programme plan or an adequate management structure a year after its launch.

Using uncommonly robust language in its first report on the 10-year Partnership for a New Generation of Vehicles (PNGV) programme, the panel says it is "disconcerting that the PNGV is essentially a year into the partnership and was unable to provide detailed and defined program plans, schedules and milestones".

The academy panel is chaired by Trevor Jones, a recently retired British motor industry executive. In a report published this week, it claims that the existing management structure of the programme is "too

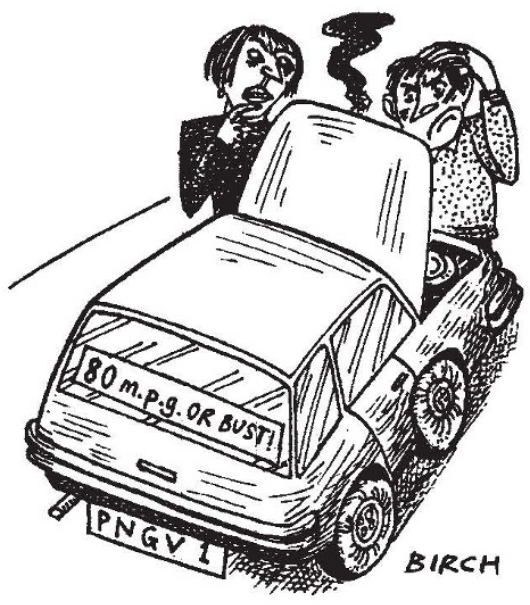

diffuse and its capability too limited" to attain PNGV's main goal, namely the development of a car with three times the fuel efficiency of existing models, equivalent to about 80 miles to the gallon.

PNGV was set up by the administration to involve the 'Big Three' US car makers General Motors, Ford and Chrysler - in research and development collaboration with government agencies, led by the commerce and energy departments. It was expected to include about $\$ 3$ billion of government research funds diverted from other programmes over 10 years, to be matched by investment from the three car companies. Most of the industry contribution would come in the later stages of the programme.

The programme was launched in September 1993 by President Bill Clinton, Vice President $\mathrm{Al}$ Gore and the presidents of the three car companies, and the group met again at the White House last month to celebrate publicly the programme's first birthday.
But, as the most visible element of Clinton's technology policy, PNGV is being watched warily both by political opponents, who see it as an unnecessary government intervention in industry, and by some scientists, who fear that it will divert government money from basic research.

The report by the National Academy of Engineering panel says that the project management lacks coherence on both the government side, where many departments and agencies are involved, and on the industry side, which the three companies are operating through their existing research collaboration body, the United States Council for Automotive Research (USCAR).

It calls for a new programme management office to take charge on the government side and for the appointment of a technical director to lead an integrated project team on the industry side.

The report also warns of budget problems as the project gathers steam and tries to draw funding from existing programmes inside different government agencies. It calls for the entire PNGV budget to appear as a single-line item in the budget now under preparation for the 1996 financial year, which begins next October, under the control of a central programme management office.

The academy panel says that PNGV urgently needs to widen its base of support to include both the general public and those congressmen who have ultimate control over its budget. "Currently, the programme is almost exclusively a Clinton administration-USCAR initiative," it warns.

But the panel also says that it was encouraged by the good relationships developing between people from government and industry engaged in the programme, and by their enthusiasm. It also found that the goals of the programme - including the 80 m.p.g. car - were attainable, if the exercise is properly managed.

So far, the response of USCAR has been muted. "We are pleased that they have recognized the significant progress this project has made in its first year," says Scott Fosgard, a spokesman for the industry group. "We believe it offers valuable insight into our programme, and will consider its recommendations closely."

Before the report appeared, Mary Good, under-secretary for commerce and the administration official with overall responsibility for PNGV, said that it was going better than planned. "It started out slowly but over the last couple of months it has begun to gel," she said, adding that the review process in August had served as an opportunity "for people to get their acts together".

Colin Macilwain 